\title{
Status of Ornamental Fish Industry in the Philippines: Prospects for Development
}

\author{
Frederick B. Muyot ${ }^{\star}$ Maria Theresa M. Mutia, Arvie Joy A. Manejar, Gency L. Guirhem, Margielyn J. Muñez
}

National Fisheries Research and Development Institute, National Freshwater Fisheries Research and Development Center, Brgy. Butong, Taal, Batangas

\section{A B S T R A C T}

The ornamental fish business is a lucrative industry worldwide with huge prospects for livelihood and trade, but the Philippines has not developed this industry to its full potential due to some constraints. This study was conducted to assess the ornamental fish industry in the Philippines using purposive survey interview and focal group discussions in major production areas in the country to determine aspects for development. Information on key stakeholders in the marine and freshwater ornamental fish sector; quantity and value of production by region and by species; and trade were generated from the study. Approximately $8,911,879$ pieces of marine ornamental fish were exchanged per year, contributing to PHP $137,165,576$ in the country's annual trade. Production of freshwater ornamental fish was 14,304,739 pieces valued at PHP $145,958,667$. The bulk of marine ornamental fish supply came from regions with coral reef areas teeming with marine ornamentals, namely: Regions IV-A (65.56\%), III (23.18\%), and VII (4.63\%). Freshwater ornamental fish were produced mainly by Regions IV-A (34.29\%), XI (35.41\%), VI (11.96\%) and III (10.43\%) which have existing local markets. The center of trade for marine ornamental fish is Metro Manila and Cebu City due to the presence of international airports. Meanwhile, freshwater ornamental trade is concentrated in major cities and municipalities given the significant number of local hobbyists. An ornamental fish development program is needed to attain the full potential of the industry with an emphasis on (1) captive breeding of marine ornamental and freshwater indigenous fish, (2) tapping the export market for freshwater ornamental fish, and (3) promoting the sustainability of wild-caught marine ornamental fish.

E-mail address: fredbmuyot@yahoo.com*

Received: March 15, 2019

Accepted: July 22, 2019
Keywords: marine ornamental fish, freshwater ornamental fish, production, trade

\section{I N T RO D UCT I O N}

$\mathrm{O}$ rnamental fish keeping is the second-largest hobby in the world with a demand for ornamental fishes steadily increasing annually. Around 2,000 species are traded yearly with $65 \%$ coming from Asia (Livengood and Chapman 2009; Ling and Lim 2005). The world ornamental fish industry is a multibillion-dollar business with demand equivalent to USD 10 billion (Dey, 2016). The export value and import value are estimated to be USD $370 \mathrm{M}$ and USD $350 \mathrm{M}$, respectively. Wholesale value is around USD $1 \mathrm{~B}$, while the retail value is USD $3 \mathrm{~B}$. Asian countries with significant production and export trade include Singapore, Sri Lanka, Malaysia, and Thailand (Ling and Lim 2005; Herath and Wijewardene 2014).
The Philippines is a major player in the ornamental fish industry being one of the largest exporters of marine ornamental fish species in the world (Orchavillo et al. 2004). Its export trade of live marine ornamental fish in 2009-2016 was 5,216MT annually valued at PHP 279.5M (USD 558,958) which is about $0.80 \%$ of the country's export trade (PSA 2016). On the other hand, the freshwater ornamental fish sector is present in the country, but there is no official trade and production data. A substantial volume of freshwater ornamental fish is also imported from other countries with 83.113 MT in 2015 worth PHP 7.533M (USD 150,663 ) which is about $5.27 \%$ of total import trade in fisheries.

The Philippine ornamental fish industry has not fully developed into a booming industry, unlike 
in other Asian countries that are now dominant players in the ornamental fish trade. The local industry stagnated in the past decade, having failed to exploit the maximum benefits of international trade. The two sectors of the ornamental fish industry in the country have contrasting production and trade methods. The marine ornamental fish sector is characterized by the gathering of wild, native, and endemic species from coral reef areas and trading them almost entirely for the export market (Muyot et al. 2019). Continuous gathering from the wild puts strong pressure on the wild populations (Bruckner 2005). With the unsustainable harvest of fish from its wild habitats and reported illegal use of cyanide, a negative impression had been imprinted on the sector. Captive breeding of marine ornamentals through aquaculture, a sustainable alternative to gathering from the wild, is emerging trend in the sector (Swet and Pedersen 2018) but the country has not made any attempts in this field.

On the other hand, the freshwater ornamental sector involves the aquaculture of various ornamental fish species that are all exotic and introduced, which are traded mainly for the local market. The sector has not yet tapped the lucrative export market even though it has been in existence for more than three decades. Locally produced fish has yet to reach international quality standards to be able to penetrate the export market. Optimistically, there is a vast opportunity for livelihood and trade for ornamental fish, but issues of the marine and freshwater ornamental fish sectors have to be identified and addressed to achieve maximum benefit.

The development of the ornamental fish industry in the country depends heavily on government initiatives and interventions. In several aquaculture species like tilapia, milkfish, and shrimps, the initiative programs by the government have resulted in the successful development of the species and may be replicated in the ornamental fisheries sector. There had been initial moves by the government on ornamental fish, specifically the inclusion of the ornamental fish as one of the target species for support and development under the Comprehensive National Fisheries Industry Development Plan (CNFIDP 2016), a government master plan formulated to facilitate the growth of the various sectors in the fisheries industry. However, comprehensive baseline information on the ornamental fish sector is lacking, making it challenging to identify appropriate programs necessary to address the challenges confronting the industry. A study along this line was therefore initiated to generate data on the present status of the ornamental fish industry and determine avenues for development to maximize the full potential of the industry in the livelihood and trade aspects. Specifically, this study aimed to: (a) make an inventory of key players in the industry, (b) determine production by volume and value, (c) describe import, export local trade; and (d) identify key issues and concerns of the industry. Through this study, recommended options for sustainable development of the industry will be generated.

\section{MATERIALS AND METHODS}

The study covered 13 provinces in ten regions for the marine ornamental fish sector and 29 provinces in 13 regions for the freshwater ornamental fish sector (Figure 1 and Table 1), focusing on identified major collection and production areas. A total of 429 respondents were interviewed for both marine and freshwater ornamental fish sectors.

Survey areas were identified through secondary data from key informant interviews of BFAR Fisheries Regulatory, Quarantine Division BFAR One-Stop Shop and BFAR Regional Offices. Target respondents for the marine ornamental fish sector were selected through interviews of exporters mainly based in Manila while respondents for the freshwater ornamental fish sector were identified through interviews of BFAR Regional Offices.

Survey interview of respondents was done using a structured questionnaire to gather information on socio-demographics, production areas, volume and value of production, type of species produced, and issues and concerns in livelihood and trade. Due to lack of information on the population of the ornamental fish sector, purposive sampling was used which focused on selecting particular individuals as stakeholders which was intended to achieve representation or comparability per stakeholder (Teddlie and Yu 2007).

Data were analyzed using Microsoft Excel 2013 to generate descriptive and frequency analysis of the study. Analyzed data were validated through the conduct of two focus group discussion (FGD) for the marine ornamental fish sector (Calatagan, Batangas and Olango Island, Cebu) and two FGDs for freshwater ornamental fish (Pila, Laguna and Toril, Davao City).

\section{RESULTS AND DISCUSSION}

\subsection{Stakeholders of the Ornamental Fish Industry in the Philippines}

The national fisherfolk registry in the country is not classified into specific sectors by commodity, 

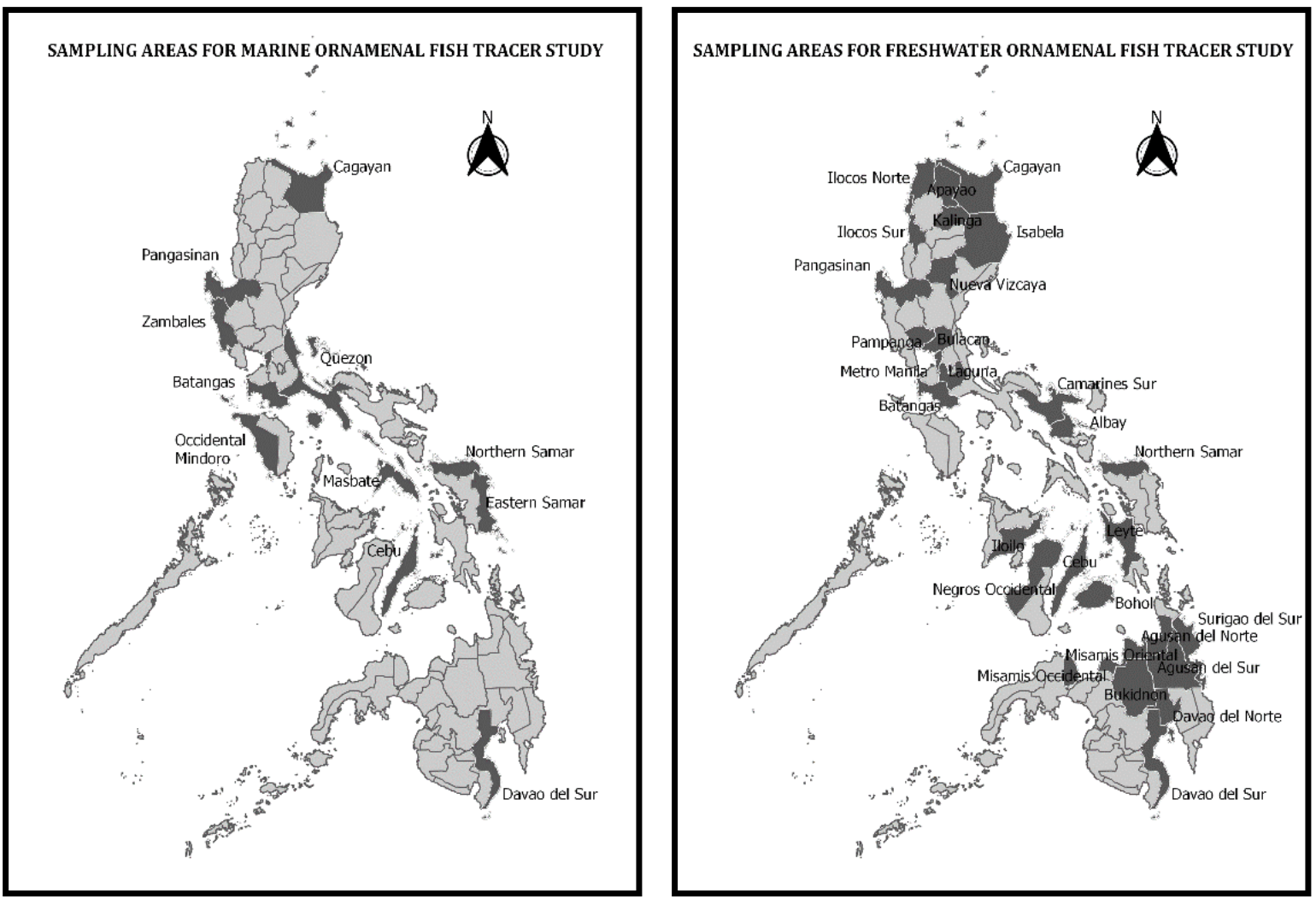

Figure 1. Study areas for the survey of the status of ornamental fish industry in the Philippines (marine ornamental fish areas in black, left figure; freshwater ornamental fish areas in white, right figure)

Table 1. Survey areas for stakeholders of the freshwater and marine ornamental fish industry in the Philippines.

\begin{tabular}{|lll|}
\hline \multicolumn{1}{|c}{ Region } & \multicolumn{1}{c|}{ Inclusive Province/s } \\
\cline { 2 - 3 } & Marine Ornamental Fish Sector & \multicolumn{1}{c|}{ Freshwater Ornamental Fish Sector } \\
\hline Region 1 (Ilocos) & Pangasinan & Apayao, Kalinga, Ilocos Norte, Ilocos sur, Pangasinan \\
Region 2 (Cagayan Valley) & Cagayan & Cagayan, Isabela, Nueva Vizcaya \\
Region 3 (Central Luzon) & Zambales & Pampanga, Bulacan \\
CAR & & Benguet \\
Region 4A (Calabarzon) & Batangas, Quezon & Batangas, Laguna \\
Region 4B (Mimaropa) & Occidental Mindoro, Marinduque & \\
Region 5 (Bicol Region) & Masbate & Albay, Camarines Sur \\
Region 6 (Western Visayas) & & Iloilo, Negros Occidental \\
Region 7 (Central Visayas) & Cebu & Cebu, Bohol \\
Region 8 (Eastern Visayas) & Northern Samar, Eastern Samar & Northern Samar, Leyte \\
Region 10 (Northern Mindanao) & & Misamis Occidental, Misamis Oriental, Bukidnon \\
Region 11(Davao) & Davao del Sur & Davao del Norte, Davao del Sur \\
Region 13 (Caraga) & & Agusan del Norte, Agusan del Sur, Surigao del Sur \\
National Capital Region & Metro Manila & Metro Manila \\
\hline
\end{tabular}


especially for a highly specific sector such as the ornamental fish industry. This study generated an estimate of the key players directly involved in the production and trade of marine and freshwater ornamental fish in the surveyed areas with 2,545 fisherfolk individuals. In comparison to the $1.6 \mathrm{M}$ total number of fisherfolk in the country (PSA 2018), the ornamental fish industry may be one of the smallest sectors of the fisheries industry. It is probably for this reason that the sector had not been given much attention in terms of government support and programs.

The marine ornamental fish sector is composed of 1,431 stakeholders composed of 1,063 producers, 319 traders, and 49 exporters, which accounted for $55.42 \%$ of all stakeholders of the two ornamental fish sectors. The key players in the marine ornamental fish industry are the divers (gatherers), traders, and exporters. The number of each type of stakeholder is presented in Table 2A. About $87.12 \%$ of all stakeholders of the marine ornamental fish sector is found in three regions, namely Region 4A-Calabarzon (38.42\%), Region 3-Central Luzon (31.77\%), and Region 7-Cebu
(16.93\%), shown in Figure 2. Divers and traders are located near collection areas which are usually found in remote rural areas. Exporters are concentrated near cities adjacent to international airports that are authorized as hubs for aquarium trade, such as in Region 7 and National Capital Region. Cebuanos may have started ornamental fish gathering because the majority of the divers were Cebuano in ethnicity whether they are located in Visayas (Cebu) or Luzon (Quezon, Zambales, Pangasinan, and Cagayan). Living conditions of divers are typically poor, generally poorer in condition than local fishers in the country. The main reasons would be the low buying price of the marine ornamental fishes from the divers and the number of the fish catch being highly dependent on the demand from traders, as dictated by the exporters. Because the collection areas are generally located in remote areas, divers could not sell their produce directly to buying stations or exporters but had to sell them through the traders at a lower price. Furthermore, educational attainment is low due to poverty, and as such, opportunities for other types of employment are limited.

Table 2A. Estimated number of stakeholders involved in the marine ornamental fish industry in surveyed areas in the Philippines.

\begin{tabular}{|lcccc|}
\hline Region & Divers & Traders/Suppliers & Exporters & Total \\
\hline Region 1(Ilocos) & 30 & 5 & 35 \\
Region 2 (Cagayan Valley) & 30 & 11 & 41 \\
Region 3 (Central Luzon) & 340 & 99 & 439 \\
Region 4A (Calabarzon) & 390 & 141 & 531 \\
Region 4B (Mimaropa) & 23 & 13 & 36 \\
Region 5 (Bicol Region) & 6 & 2 & 9 & 8 \\
Region 7 (Central Visayas) & 201 & 33 & & 243 \\
Region 8 (Eastern Visayas) & 35 & 12 & 47 \\
Region 11 (Davao) & 8 & 3 & 40 & 11 \\
National Capital Region & & & $\mathbf{4 9}$ & $\mathbf{1 , 4 3 1}$ \\
\hline \multicolumn{1}{c}{ Total } & $\mathbf{1 , 0 6 3}$ & $\mathbf{3 1 9}$ & & 40 \\
\hline
\end{tabular}

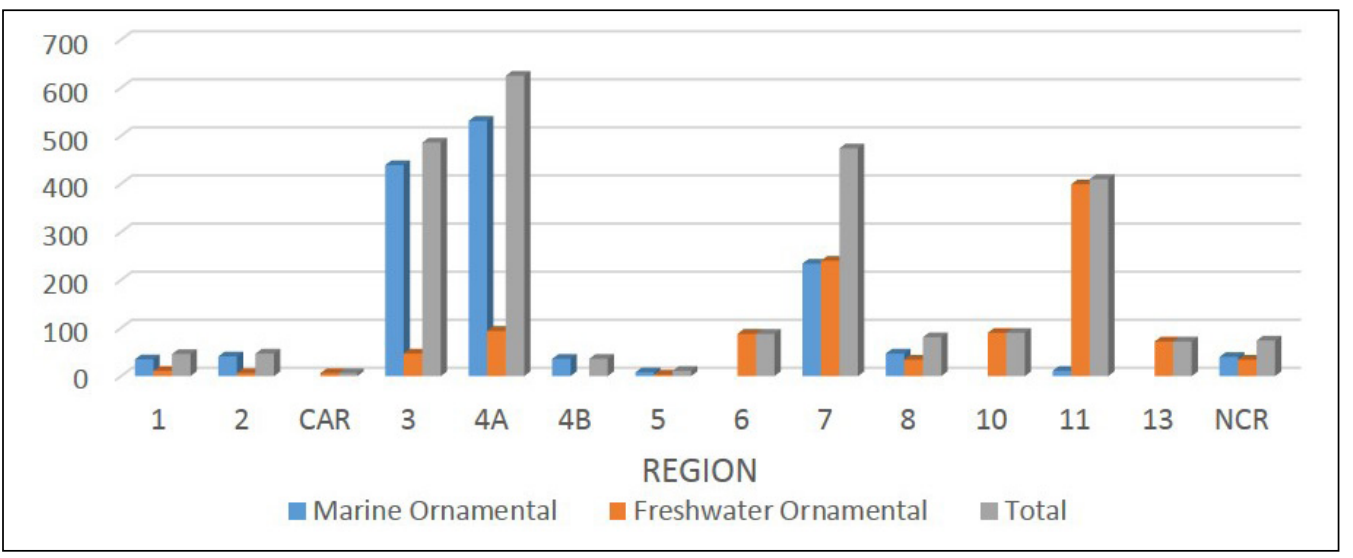

Figure 2. Number of stakeholders per region in the marine and freshwater ornamental fish industry 
On the other hand, the freshwater ornamental fish sector has 1,114 stakeholders accounting for $43.79 \%$ of all stakeholders of the two sectors. The key players of the freshwater ornamental fish sector are the 886 producers (commercial, backyard, and hobbyist), 55 traders, and 173 wholesalers/retailers (pet shop owners and importers). Table 2B shows the number of individuals per type of stakeholder in the sector. The sector has a large proportion of stakeholders located in six regions: Region 11-Davao (35.46\%); Region 7-Cebu (20.97\%); Region 4A-Calabarzon (8.57\%); Region 6-Western Visayas (8.02\%); Region 10-Northern Mindanao (7.29\%); and Region 13-Caraga (6.56\%) as shown in Figure 2. Producers of freshwater ornamental fish, both commercial and backyard, and traders are located in both rural and urban areas which are near trading areas or areas where ornamental fish keeping is popular as a hobby. Wholesalers/retailers are situated in major cities and towns while importers are found in Manila.

\subsection{Total production of marine and freshwater ornamental fish}

The total annual production of the entire ornamental fish industry in the Philippines in 2016 was estimated by this study at $23,216,618$ pieces valued at PHP 283,124,243. Figure 3 shows the percentage share by quantity and by value of the two sectors. By quantity, the percentage contribution of the freshwater ornamental fish sector (61.61\%) was higher than the marine ornamental fish sector (38.39\%). In terms of value, the marine ornamental fish sector shared $48.45 \%$ while freshwater ornamental fish sector contributed $51.55 \%$.

Table 2B. Estimated number of stakeholder households involved in the freshwater ornamental fish industry in surveyed areas in the Philippines.

\begin{tabular}{|c|c|c|c|c|c|c|c|}
\hline \multirow[b]{2}{*}{ Region } & \multicolumn{2}{|c|}{ Producer } & \multicolumn{2}{|c|}{ Trader } & \multicolumn{2}{|c|}{ Wholesaler/Retailer } & \multirow[t]{2}{*}{ Total } \\
\hline & Commercial & Backyard & Hobbyist & Traders & Petshop & Importer & \\
\hline Region 1 (Ilocos) & 1 & 9 & & & 1 & & 11 \\
\hline Region 2 (Cagayan Valley) & & 3 & & & 3 & & 6 \\
\hline CAR & & 1 & & & 5 & & 6 \\
\hline Region 3 (Central Luzon) & 32 & & & 12 & 3 & & 47 \\
\hline Region 4A (Calabarzon) & 27 & 48 & 2 & 4 & 13 & & 94 \\
\hline Region 5(Bicol) & - & - & - & - & 3 & - & 3 \\
\hline Region 6 (Western Visayas) & 25 & 25 & 15 & 9 & 10 & & 84 \\
\hline Region 7 (Central Visayas) & & 30 & 200 & & 14 & & 244 \\
\hline Region 8 (Eastern Visayas) & & 20 & & & 14 & & 34 \\
\hline Region 10 (Northern Mindanao) & & 50 & & & 30 & & 80 \\
\hline Region 11 (Davao) & 70 & 178 & 100 & 30 & 21 & & 399 \\
\hline Region 13 (Caraga) & & 40 & 10 & & 22 & & 72 \\
\hline NCR & - & - & - & - & 30 & 4 & 34 \\
\hline Total & 155 & 404 & 327 & 55 & 169 & 4 & 1,114 \\
\hline
\end{tabular}
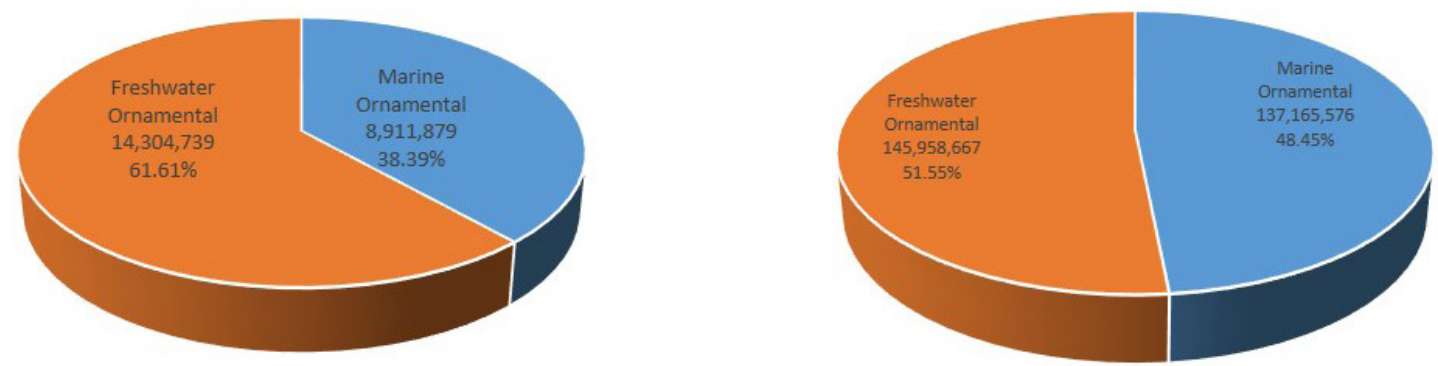

Figure 3. Percentage contribution by quantity in pieces (left) and by value in PHP (right) of the annual production of marine and freshwater ornamental fish industry in the Philippines in 2016. 


\subsection{Marine Ornamental Fish Collected from Production Areas}

Marine ornamental fishes are noted to be gathered or collected from coral reef areas through diving using nets and traps. The total annual production of marine ornamental fish in 2016 was $8,911,879$ pieces valued at PHP 137,165,576 (USD 2,743,311). Figure 4 shows the key production areas of marine ornamentals in the country. The main producing regions are Region 4A, specifically the provinces of Quezon and Batangas (5,843,071 pieces); Region 3, particularly the province of Zambales (2,065,866 pieces); and Region 7, specifically the province of Cebu $(412,934$ pieces) which collectively shared $93.38 \%$ by quantity of all marine ornamental fish in the country. By value, these three regions had shared $94.5 \%$ of all marine ornamental fish valued at PHP 104,696,140 with Regions $4 \mathrm{~A}, 3$, and 7 having contributed $70.8 \%, 18.2 \%$, and 5.5\%, respectively (Figure 5).

From the surveys and FGDs, it was noted that the production of marine ornamental fish was dictated by the demand from exporters who were mostly dependent on demand orders from importing countries. The main reason for the large volume of fish produced by the three major-producing regions is because of the presence of wide coral reef cover in these areas and the correspondingly high number of diver-gatherers. In some areas, production was relatively low due to local regulations and restrictions, particularly on the ban on collection of marine ornamentals due to suspected use of cyanide as in the case of Zambales in Central Luzon Region and Northern Samar of the Eastern Visayas Region. The ban on the use of compressors in diving is imposed in all municipalities which limited the gathering to shallow areas. Adverse weather conditions from September to February also hinders collection. Thus, the supply of fish is low during these months.

\subsection{Freshwater Ornamental Fish Production}

Freshwater ornamental fish were produced through captive breeding and raising of fish in culture facilities although some species may be imported at a smaller size and grown to marketable size and traded locally. Total annual production of freshwater ornamental fish for the duration of the study in 2016 was 14,304,739 pieces amounting to PHP 145,958,667. These were mainly from by four regions, namely: Region 4A-Calabarzon, specifically from Batangas and Laguna (6,331,416 pieces); Region 11-Davao from Davao del Sur and Davao del Norte $(2,824,891$ pieces); Region 6-Western Visayas from Iloilo and Negros Occidental (2,622,522 pieces); and Region 3-Central Luzon Pampanga and Bulacan (2,409,890 pieces), as shown in Figure 4. These four regions produced $92.1 \%$ of all freshwater ornamental fish. Region 11-Davao had the highest contribution by value at $35.4 \%$, fol-

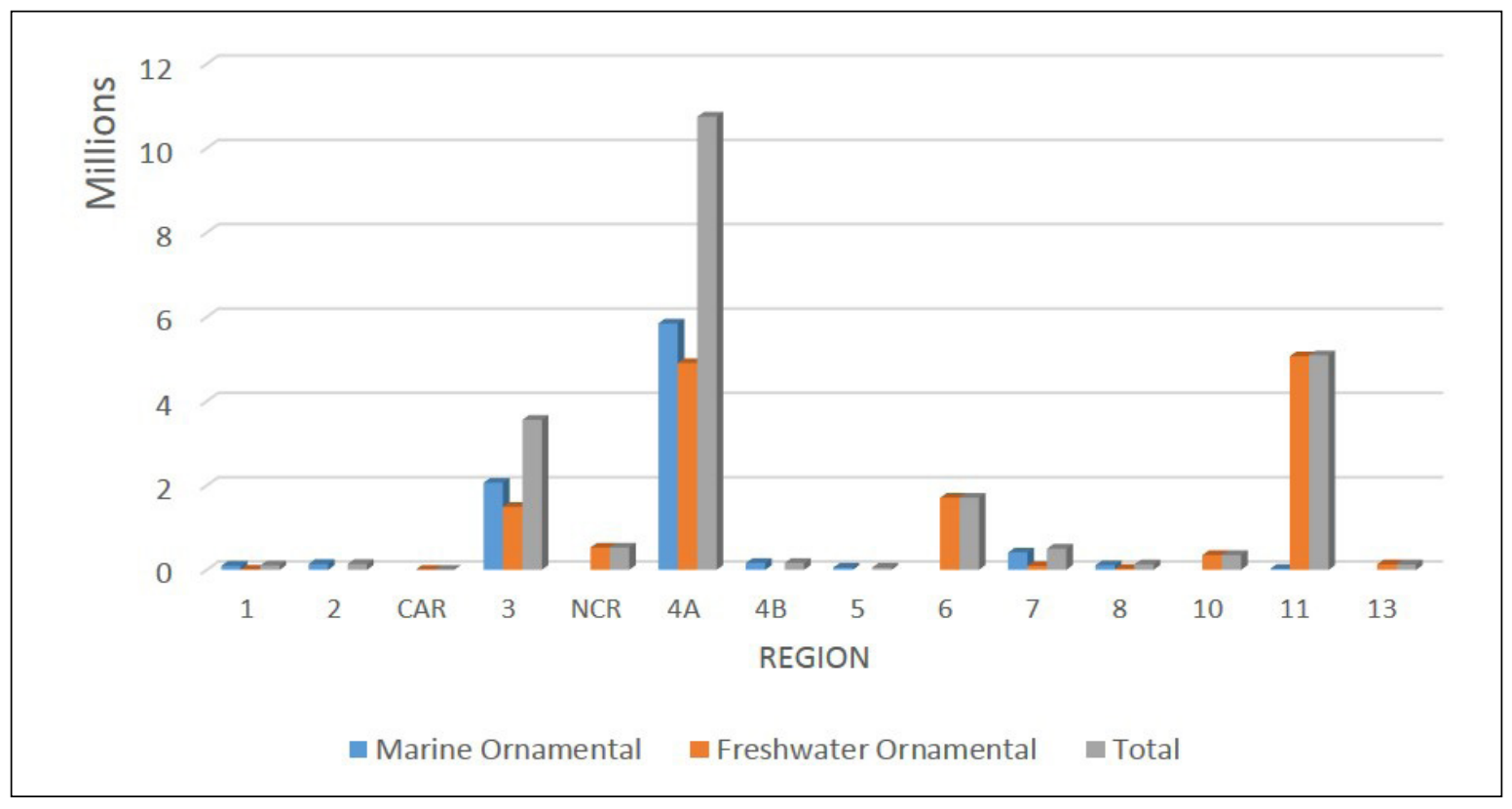

Figure 4. Annual production by quantity (in pieces) of marine and freshwater ornamental fish sector in key production areas in the Philippines. 


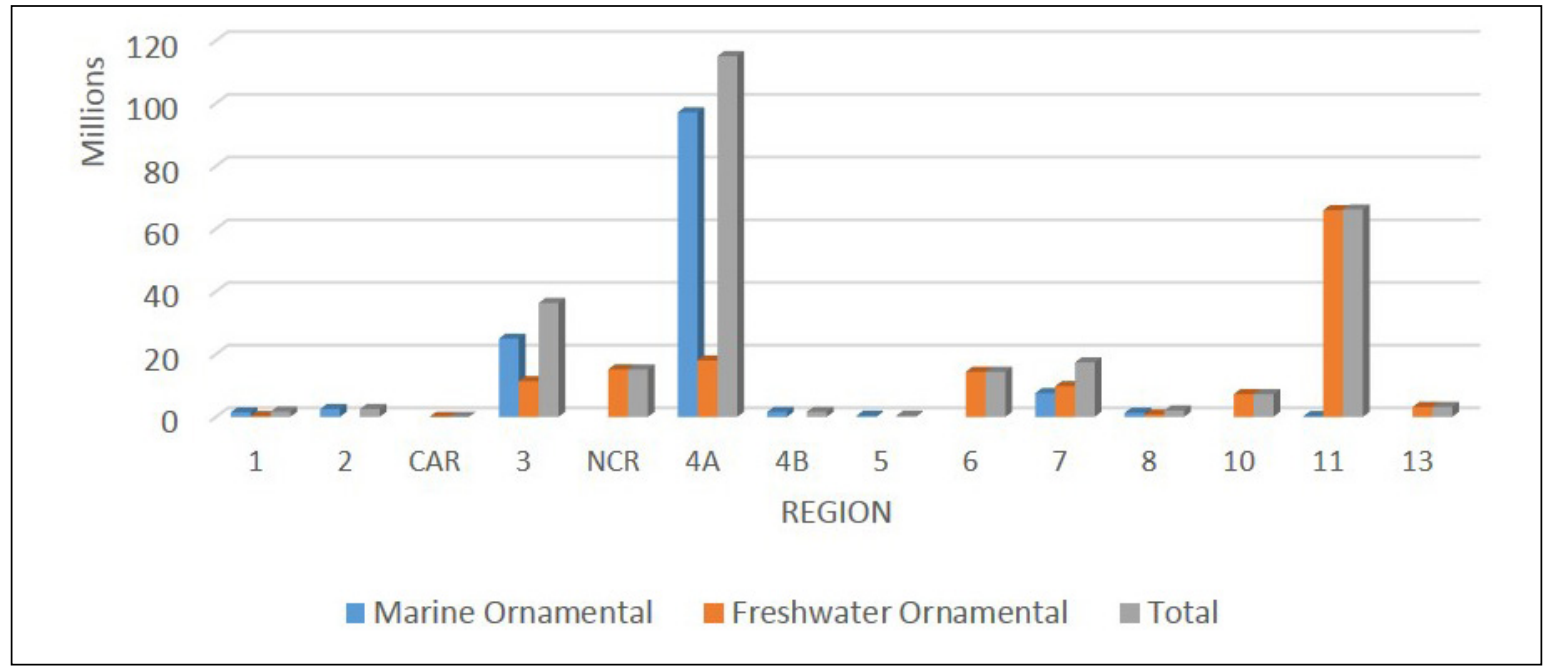

Figure 5. Annual production by value (in PHP) of marine and freshwater ornamental fish sector in key production areas in the Philippines

lowed by Region 4A-Calabarzon, Region 3-Central Luzon and Region 6-Western Visayas with $34.3 \%$, $10.4 \%$, and $12.0 \%$, respectively (Figure 5).

The massive production of freshwater ornamental fish in four major producing regions was mainly attributed to a high proportion of producers in these areas. Calabarzon and Central Luzon Regions were more productive than the other regions with a percentage of production by quantity that is more than four times its percentage of producers in the area. The main reason for this higher productivity in the two regions was the use of large ponds for culture in comparison to backyard type or small-scale rearing facilities in the other regions aside from the availability of commercial feeds and other freshwater aquaculture support facilities.

\subsection{Species collected or produced}

\subsubsection{Species produced marine and freshwater}

Results showed that the ornamental fish produced in the country comprised of 1,294 species with 1,200 marine ornamental species and 94 freshwater ornamental species (Table 3). All marine species were wild-caught and classified as native or endemic. In contrast, all freshwater species were classified as captive-bred and exotic or introduced.

\subsubsection{Marine ornamental species}

The secondary data from BFAR One-Stop Shop (2015) showed that there are 1,200 species of marine ornamental fish traded by the ornamental fish industry. These traded species, as classified by this study into scientific groups, belonged to 144 families and 67 fish groups (Table 3). These include fish (46 families, 31 groups, and 904 species), invertebrates (8 families, 8 groups, and 247 species) and miscellaneous species (30 families, 28 groups, and 49 species). The largest groups were wrasses (106 species), gobies (70 species), damselfishes (46 species), butterflyfishes (36 species), grouper/Pseudochromis (36 species), anthias (32 species), anemones (32 species), shrimps (32 species), angelfishes (28 species), and blennies (27 species). All of these traded fish are native or endemic species and are entirely collected from the wild habitats. There was no marine ornamental fish that had been recorded as captive-bred. Among the traded marine ornamental fish (Table 4), the top species were chromis (6.69\%), false percula clownfish $(4.61 \%)$, firefish goby (3.35\%), damselfish (2.97\%), pacific neon goby (2.69\%), and three-striped damselfish (2.66\%). The major fish groups caught from five major producing provinces are presented in Table 5 . Wrasse, gobies, damselfish, butterflyfish, and angelfish were generally collected from the major producing provinces of Zambales, Quezon, Pangasinan, Cagayan, and Mindoro Occidental. Other major species were collected from selected provinces only.

Coral reef areas in Luzon and Visayas were generally in the poor or fair category (Licuanan et al. 2017; Aliño et al. 2012). This state of coral reef coupled with the continuous collection of marine ornamental fish put intense pressure in the wild population that may result in its further decline. Such situation 
Table 3. Species produced and traded by ornamental fish industry in the Philippines (list of species produced \& traded) to classify marine as native; all gathered from the wild; freshwater all exotic/non-native

\begin{tabular}{|lccccc|}
\hline \multicolumn{1}{|c}{ Sector } & No. Family & No. Fish Groups & No. Species & No. Variety & $\begin{array}{c}\text { Source \& means of } \\
\text { production }\end{array}$ \\
\hline $\begin{array}{l}\text { Marine } \\
\text { Ornamental } \\
\text { Freshwater } \\
\text { Ornamental }\end{array}$ & 144 & 67 & 1,200 & & $\begin{array}{l}\text { All native or endemic; } \\
\text { all collected from wild } \\
\text { All exotic/introduced; } \\
\text { mainly captive-bred }\end{array}$ \\
\hline Total & 17 & & 94 & 422 & 422 \\
\hline
\end{tabular}

Table 4. Top 10 Marine ornamental fish species collected from production areas, by quantity (pcs) and by value (PHP) in 2016.

\begin{tabular}{|c|c|c|c|}
\hline Species & $\begin{array}{c}\text { Percentage share by } \\
\text { quantity (\%) }\end{array}$ & Species & $\begin{array}{c}\text { Percentage share by value } \\
(\%)\end{array}$ \\
\hline $\begin{array}{l}\text { 1. Green chromis } \\
\text { (Chromis viridis) }\end{array}$ & 6.69 & $\begin{array}{l}\text { 1. Percula clownfish } \\
\text { (Amphiprion ocellaris) }\end{array}$ & 3.14 \\
\hline $\begin{array}{l}\text { 2. Percula clownfish } \\
\text { (Amphiprion ocellaris) }\end{array}$ & 4.61 & $\begin{array}{l}\text { 2.Firefish goby (Nematel- } \\
\text { eotris magnifica) }\end{array}$ & 2.88 \\
\hline $\begin{array}{l}\text { 3. Firefish goby } \\
\text { (Nemateleotris magnifica) }\end{array}$ & 3.35 & $\begin{array}{l}\text { 3. Blue tang } \\
\text { (Acanthurus coeruleus) }\end{array}$ & 2.69 \\
\hline $\begin{array}{l}\text { 4. Damselfish } \\
\text { (Abudefdufsp.) }\end{array}$ & 2.97 & $\begin{array}{l}\text { 4. Green chromis } \\
\text { (Chromis viridis) }\end{array}$ & 2.11 \\
\hline $\begin{array}{l}\text { 5. Pacific neon goby } \\
\text { (Gobiodon astronasum) }\end{array}$ & 2.69 & $\begin{array}{l}\text { 5. Clown triggerfish (Bal- } \\
\text { istoides conspicillum) }\end{array}$ & 2.03 \\
\hline $\begin{array}{l}\text { 6. Three-stripe damsel } \\
\text { (Dascyllus trimaculatus) }\end{array}$ & 2.66 & $\begin{array}{l}\text { 6. Flagfin angelfish (Apo- } \\
\text { lemichthys trimaculatus) }\end{array}$ & 1.99 \\
\hline $\begin{array}{l}\text { 7. Yellowtail blue damsel } \\
\text { (Chrysiptera parasema) }\end{array}$ & 2.39 & $\begin{array}{l}\text { 7. Coral beauty angelfish } \\
\text { (Centropyge bispinosus) }\end{array}$ & 1.98 \\
\hline $\begin{array}{l}\text { 8. Domino damsel } \\
\text { (Dascyllus melanurus) }\end{array}$ & 2.29 & $\begin{array}{l}\text { 8. Emperor angelfish } \\
\text { (Pomacanthus } \\
\text { imperator) }\end{array}$ & 1.97 \\
\hline $\begin{array}{l}\text { 9. Blue damsel } \\
\text { (Chrysiptera cyanea) }\end{array}$ & 1.66 & $\begin{array}{l}\text { 9. Green mandarin goby } \\
\text { (Pterosynchiropus } \\
\text { splendidus) }\end{array}$ & 1.7 \\
\hline $\begin{array}{l}\text { 10. Tomato clownfish } \\
\text { (Amphiprion frenatus) }\end{array}$ & 1.42 & $\begin{array}{l}\text { 10. Powder brown tang } \\
\text { (Acanthurus japonicus) }\end{array}$ & 1.33 \\
\hline Others & 69.26 & Others & 78.07 \\
\hline
\end{tabular}


Table 5. Dominant species collected from the major marine ornamental fish-producing provinces in the Philippines in 2016.

\begin{tabular}{|c|c|c|}
\hline Province & $\begin{array}{l}\text { Percentage share of } \\
\text { production }\end{array}$ & Dominant species collected (\% by composition) \\
\hline Zambales & $35 \%$ & $\begin{array}{l}\text { Chromis (31.20\%); butterfly fish (17.62\%); angelfish }(9.93 \%) \text {; } \\
\text { wrasse ( } 8.51 \%) \text {; damselfish }(8.26 \%) \text {; tang (6.70\%); clownfish } \\
(6.0 \%) \text {; anthias (5.63\%); bannerfish }(5.36 \%) \text {; shrimp }(3.15 \%)\end{array}$ \\
\hline Batangas & $15 \%$ & $\begin{array}{l}\text { Wrasse }(28.49 \%) \text {; goby }(18.63 \%) \text {; parrotfish }(15.27 \%) \text {; anthias } \\
(12.21 \%) \text {; bleny }(9.47 \%) \text {; } \\
\text { chromis }(6.11 \%) \text {; clownfish }(3.42 \%) \text {; tang }(2.75 \%) \text {; goatfish } \\
(2.44 \%) \text {; angelfish }(0.79 \%)\end{array}$ \\
\hline Quezon & $12 \%$ & $\begin{array}{l}\text { Cardinal fish (45.4\%); damselfish (12.0\%); angelfish (11.2\%); } \\
\text { shrimp (9.6\%); tang ( } 5.8 \%) \text {; rabbitfish }(5.2 \%) \text {; grouper/pseu- } \\
\text { dochromis (3.8\%); wrasse (2.9\%); butterfly fish (1.8\%); goby } \\
(1.0 \%)\end{array}$ \\
\hline Pangasinan & $4 \%$ & $\begin{array}{l}\text { Eel }(20.65 \%) \text {; damselfish }(18.33 \%) \text {; goby }(18.09 \%) \text {; chromis } \\
(13.48 \%) \text {; angelfish }(9.25 \%) \text {; shrimp }(7.37 \%) \text {; clownfish } \\
\text { (4.85\%); butterfly fish }(3.62 \%) \text {; scorpionfish (1.67\%); grunts/ } \\
\text { sweetlips ( } 0.89 \%)\end{array}$ \\
\hline Cagayan & $3 \%$ & $\begin{array}{l}\text { Wrasse }(37.87 \%) \text {; anthias }(18.98 \%) \text {; angelfish }(16.38 \%) \text {; but- } \\
\text { terfly fish }(10.09 \%) \text {; damselfish }(9.68 \%) \text {; clownfish }(2.44 \%) \text {; } \\
\text { triggerfish }(1.56 \%) \text {; tang }(1.49 \%) \text {; shark }(0.74 \%) \text {; blenny } \\
(0.22 \%)\end{array}$ \\
\hline Mindoro Occidental & $1 \%$ & $\begin{array}{l}\text { Goby }(45.52 \%) \text {; damselfish }(40.34 \%) \text {; wrasse }(7.82 \%) \text {; tang } \\
(4.72 \%) \text {; butterfly fish }(0.55 \%) \text {; blenny }(0.42 \%) \text {; angelfish } \\
(0.36 \%) \text {; clownfish }(0.22 \%) \text {; triggerfish }(0.04 \%)\end{array}$ \\
\hline
\end{tabular}

occurred in many other countries with similar practice of gathering wild marine ornamental fish, and a significant decrease in wild populations was reported (Bruckner 2005; Wood 2001). It is therefore crucial that sustainable collection of fish is practiced in these areas to ensure continued productivity over long period. A national policy regulating the collection of marine ornamental fish was lacking and needed to be developed. Some local government units, however, impose restrictions on the gathering and transport of marine ornamental fish in their respective localities, as in the case of Zambales and Northern Samar. Such regulations had been imposed as a result of their assessment of the present threat to wild habitats and fish populations, which are noted to be in dire condition that needs to be protected. These restrictions, however, had negative implications on the livelihood of the diver households with no source of livelihood other than gathering of marine ornamental fish. The affected diver-gatherers, therefore, must be included as beneficiaries of livelihood programs of the government. In major marine ornamental fish producing regions, local government units deemed the marine ornamental fish sector to be a sustainable industry that provides livelihood benefits to locals. Appropriate programs are implemented to ensure the sustainability of the resources such as declaration of marine sanctuary reserves in their areas.

\subsubsection{Freshwater ornamental species}

Freshwater ornamental fishes in the local ornamental fish industry are comprised of 422 varieties of 94 fish species belonging to 17 Families (Table 6). Among these fishes, the highest number of varieties were identified to be goldfish (38 varieties), Japanese koi (37 varieties), guppy (37 varieties), molly (27 varieties), platy (16 varieties), fighting fish (12 varieties), and swordtail (11 varieties). The highest number of species produced were Japanese koi $(25.35 \%)$, molly (23.67\%), goldfish $(20.60 \%)$, swordtail $(6.72 \%)$, and platy (6.41\%). Freshwater ornamental fish species and varieties traded in the country are all exotic or introduced species. Almost all of the traded fishes were produced through captive breeding. However, there was no record of native species being bred in captivity and traded as freshwater ornamental fish. The main species produced by major freshwater ornamental fish producing provinces are presented in Table 7. 
Table 6. Top 10 Freshwater Species Produced Locally, by Quantity (pcs) and by Value (PHP)

\begin{tabular}{|c|c|c|c|}
\hline Species & $\begin{array}{c}\text { Percentage share } \\
\text { by quantity (\%) }\end{array}$ & Species & $\begin{array}{l}\text { Percentage share } \\
\text { by value }(\%)\end{array}$ \\
\hline 1. Japanese koi (Cyprinus carpio) & 25.35 & 1. Cichlids (Cichlasoma sp) & 30.70 \\
\hline 2. Molly (Poecilia sphenops) & 23.67 & 2. Japanese koi (Cyprinus carpio) & 23.02 \\
\hline 3. Goldfish (Carassius auratus) & 20.60 & 3. Goldfish (Carassius auratus) & 21.32 \\
\hline 4.Swordtail (Xiphophorus helleri) & 6.72 & 4. Fighting fish (Betta splendens) & 4.76 \\
\hline 5. Platy (Xiphophorus maculatus) & 6.41 & 5. Molly (Poecilia sphenops) & 3.62 \\
\hline 6. Guppy (Poecilia reticulata) & 3.84 & 6. Guppy (Poecilia reticulata) & 3.21 \\
\hline $\begin{array}{l}\text { 7. Cardinal tetra (Paracheroidon } \\
\text { axelrodi) }\end{array}$ & 2.38 & 7. Platy (Xiphophorus maculatus) & 2.52 \\
\hline $\begin{array}{l}\text { 8. Hammerhead shark (Pangasius } \\
\text { sp.) }\end{array}$ & 2.36 & $\begin{array}{l}\text { 8. Cardinal Tetra (Paracheroidon } \\
\text { axelrodi) }\end{array}$ & 1.65 \\
\hline 9. Zebrafish (Danio rerio) & 2.30 & 9. Arowana (Scleropages sp.) & 1.34 \\
\hline $\begin{array}{l}\text { 10. Tiger barb (Puntigrus tetra- } \\
\text { zona) }\end{array}$ & 1.92 & $\begin{array}{l}\text { 10. Hammerhead shark (Pangasi- } \\
\text { us sp.) }\end{array}$ & 1.16 \\
\hline Others & 6.39 & Others & 6.7 \\
\hline
\end{tabular}

Table 7. Dominant species produced by major freshwater ornamental fish producing provinces in the Philippines in 2016.

\begin{tabular}{|c|c|c|}
\hline Province & $\begin{array}{l}\text { Percentage share of production } \\
\text { from total national production }\end{array}$ & $\begin{array}{l}\text { Dominant species collected (\% by } \\
\text { composition) }\end{array}$ \\
\hline Pampanga & $16.42 \%$ & $\begin{array}{l}\text { Japanese koi }(71.55 \%) \text {; goldfish } \\
(15.72 \%) \text {; sharkminnow }(9.51 \%) \text {; } \\
\text { catfish }(1.45 \%) \text {; cichlid }(1.02 \%) \text {; molly } \\
(0.34 \%) \text {; barb }(0.31 \%) \text {; guppy }(0.11 \%)\end{array}$ \\
\hline Batangas & $5.38 \%$ & $\begin{array}{l}\text { Fighting fish (50.74\%); platy }(27.22 \%) \text {; } \\
\text { swordtail (8.36\%); molly (17.71\%); } \\
\text { Japanese koi (2.41\%); angelfish } \\
(2.15 \%) \text {; guppy }(2.09 \%) \text {; goldfish } \\
(0.38 \%)\end{array}$ \\
\hline Laguna & $38.54 \%$ & $\begin{array}{l}\text { Molly }(14.86 \%) \text {; platy (13.39); Jap- } \\
\text { anese koi }(7.94 \%) \text {; cichlid }(7.87 \%) \text {; } \\
\text { catfish }(7.54 \%) \text {; goldfish }(7.01 \%) \text {; } \\
\text { tetra }(6.86 \%) \text {; barb }(5.84 \%) \text {; angelfish } \\
(5.31 \%) \text {; zebrafish }(5.15 \%)\end{array}$ \\
\hline Davao del sur & $38.42 \%$ & $\begin{array}{l}\text { Goldfish }(51.17 \%) \text {; Japanese koi } \\
(32.34 \%) \text {; fighting fish }(11.39 \%) \text {; molly } \\
(4.01 \%) \text {; swordtail }(0.58 \%) \text {; guppy } \\
(0.50 \%)\end{array}$ \\
\hline
\end{tabular}


Table 8. Export, import, and local trade of ornamental fish in the Philippines.

\begin{tabular}{|c|c|c|c|c|}
\hline \multirow[t]{2}{*}{ Sector } & \multirow{2}{*}{$\begin{array}{l}\text { Quantity } \\
\text { (pcs) }\end{array}$} & \multirow{2}{*}{$\begin{array}{l}\text { Value (PHP/ } \\
\text { USD) }\end{array}$} & \multicolumn{2}{|c|}{ Destination of export \& local trade, source of import } \\
\hline & & & $\%$ by Quantity & $\%$ by Value \\
\hline \multicolumn{5}{|c|}{ Marine Ornamental } \\
\hline A. Export & $8,554,729$ & $\begin{array}{l}\text { PHP 235,496,302 } \\
\text { (USD 4,709,926) }\end{array}$ & $\begin{array}{l}\text { USA (44.13\%); China } \\
\text { (15.65\%); Hong Kong } \\
\text { (7.77\%); Japan (6.67\%); } \\
\text { Taiwan (4.69\%); Canada } \\
\text { (4.87\%); UK (3.93\%); } \\
\text { others (12.29\%) }\end{array}$ & $\begin{array}{l}\text { USA }(50.97 \%) \text {; Hong } \\
\text { Kong }(8.09 \%) \text {; Taiwan } \\
(6.5 \%) ; \text { Japan }(6.13 \%) ; \\
\text { China }(4.44 \%) \text {; Canada } \\
(3.81 \%) \text { others }(20.06 \%)\end{array}$ \\
\hline \multicolumn{5}{|l|}{$\begin{array}{l}\text { Freshwater } \\
\text { Ornamental }\end{array}$} \\
\hline A. Import & 649,571 & $\begin{array}{c}\text { PHP 3,359,700 } \\
\text { (USD 67,194) }\end{array}$ & $\begin{array}{l}\text { Indonesia }(48.52 \%) ; \\
\text { Thailand }(20.38 \%) ; \\
\text { Hong Kong }(11.77 \%) \text {; } \\
\text { Singapore }(7.65 \%) ; \\
\text { Malaysia }(3.35 \%) ; \\
\text { China }(3.02 \%) \text {; Taiwan } \\
(2.74 \%) \text {; others }(2.57 \%)\end{array}$ & $\begin{array}{l}\text { Indonesia }(27.61 \%) ; \\
\text { Malaysia }(22.02 \%) \text {; Hong } \\
\text { Kong }(13.75 \%) \text {; Thailand } \\
(9.17 \%) \text {; Taiwan }(9.0 \%) ; \\
\text { Singapore }(8.36 \%) \text {; others } \\
10.09 \%)\end{array}$ \\
\hline B. Local Trade & $14,304,739$ & $\begin{array}{l}\text { PHP 145,958,650 } \\
\text { (USD 2,919,173) }\end{array}$ & $\begin{array}{l}\text { NCR }(51.51 \%) ; \text { Region } \\
4 \text { A (17.68\%); Region } \\
10(6.37 \%) \text {, Region } \\
6(5.26 \%) \text {, Region } 3 \\
(4.78 \%) \text {, Region } 7 \\
(3.66 \%) \text {; others }(10.74 \%)\end{array}$ & \\
\hline
\end{tabular}

\subsection{Ornamental Fish Trade and Opportunities for Industry Development}

\subsubsection{Total trade}

The trade of ornamental fish industry in the country involved the export of marine ornamental fishes and local and import trade of freshwater ornamental fishes. The total trade of ornamental fish was estimated to be $23,509,039$ pieces in 2017 valued at PHP 235,496,302 (USD 4,709,926), as shown in Table 8 . The combined local and import trade of freshwater ornamental fish had a higher share in terms of quantity (63.61\%) but in terms of value, had a lower contribution (38.80\%). In contrast, the export trade of marine ornamental fish had lower percentage share by quantity (36.39\%) but with considerably higher percentage share in terms of value (61.20\%) due mainly to high market price of marine ornamental fishes.

\subsubsection{Export trade}

Marine ornamental fish were all traded for export to other countries. There was no reported export trade of freshwater ornamental species documented by this study. The study estimated the value of exported marine ornamental fish at PHP 593,906,421 (USD $11,878,128)$. The leading destinations of exported fish were USA, China, Hong Kong, Japan, Taiwan, Canada, and UK. Based on government data on export trade of the country between 2009 to 2016 (BFAR 2014; PSA 2016), the marine ornamental fish industry registered a relatively stable export statistic which ranged from 5,166 MT to 6,786 MT valued at PHP 260,950,000 to PHP 306,626,000 with mean export of 279,479,000 (5,216 pieces). The highest trade figure was in 2016 and lowest in 2010. Among the exported products of the country during these periods, marine ornamental fishes ranked 7th to 8 th and were higher than those of round scad and sea cucumber exports. In 2016, it ranked 8th among export commodities (BFAR 2014) valued at PHP $284 \mathrm{M}$, representing $0.81 \%$ of the total fishery export. It should be noted that trade values reported in the Philippines Fisheries Profile were lower than the estimated export values observed by this study. The reason for the difference was that the basis for the estimate in this current study was the actual buying price at exporter level while the official government data was based on the indicated value of export by the exporters which often is underdeclared for taxation purposes.

\subsubsection{Import}

The import trade of ornamental fish involved freshwater ornamental species only. A total of 649,571 
pieces freshwater ornamental fish valued at PHP 3,359,700 (USD 67,194) were imported in 2015 (BFAR 2015). The main species imported by the country were tetra $(52.05 \%)$, goldfish $(16.80 \%)$, barb $(5.01 \%)$, arowana $(3.68 \%)$, and fighting fish $(3.66 \%)$. In terms of value, the top imported species were arowana $(37.17 \%)$, discus $(16.05 \%)$, tetra $(15.22 \%)$, cichlid $(8.17 \%)$, and goldfish (7.45\%). Imported freshwater ornamental fish mainly came from Indonesia, Thailand, Hong Kong, Singapore, Malaysia, China, and Taiwan. There was no recorded importation of marine ornamental fish.

\subsubsection{Local trade}

Local trade mainly involved freshwater ornamental fish species with an estimated 14,304,739 pieces traded annually valued at PHP 145,958,667 (USD 2,919,173). Highest local trade was recorded in NCR and Region 4A. Local trade of marine ornamental fish was not documented in this study although it is present but is seen to be insignificant and limited to very few hobbyists due to the prohibitive cost of maintenance of marine aquarium set up. There was no official government record of local trade on freshwater ornamental fish but based on data gathered by this study, estimated quantity requirement by the local market represented by petshops in the surveyed areas was $11,298,000$ pieces. This was less than the estimated local production, indicating surplus production of locally produced fish over the local buying market.

\subsection{Opportunities for livelihood and trade}

Marine ornamental fish gathering from the wild could be limited by the available resources in the wild habitats, making production unsustainable and unpredictable. Thus, there is an urgent need for an alternative source other than the wild population. Marine ornamental fish aquaculture, the breeding and production of fish in captivity, is an emerging opportunity in the sector. More recently, the US market prefers captive-bred marine ornamentals, although such fishes may be expensive than wild-caught fishes. In response to this, many countries are now geared towards the production of captive-bred some species of marine ornamental fish, and this has augmented their export trade thus reducing the pressure on wild populations of the said species (Domínguez and Botella 2014; Kumar et al. 2015; Rao and Kumar 2014). Captive breeding is a sustainable means of production, and demand for captive-bred fish is increasing due to ecological concerns related to wild-caught fishes. At present, there are about 338 species of marine ornamental fish and invertebrates that have been reported as captive-bred and 36 species are known to be commonly available in the ornamental fish trade (Swet and Pedersen 2018). The breeding of marine ornamental fish in captivity is still at its development stage with many challenges limiting its maximum potential (Moorhead and Zeng 2010). Presently, the Philippines has not yet ventured into captive-breeding of marine ornamental fish, and no attempt on this field has been recorded yet. It is therefore crucial that the country starts its breeding program for marine ornamental fish to be able to enter the captive-bred market as well as assure its production for export in the future.

On the other hand, the opportunity for the freshwater ornamental fish industry sector is in the export market, which the country has not yet been able to tap. While other major producing countries like Singapore, Sri Lanka, Malaysia, Czech Republic, and Thailand are leading exporters (Dey 2016; Ling and Lim 2005; Herath and Wijewardene 2014), the Philippines has been lagging with no export trade. There is a need for the country to be able to export its freshwater ornamental fish and lessen its importations. Freshwater ornamental fish export trade is a highly competitive market that requires high-quality fish at competitive prices. To be able to penetrate the lucrative export market, the local industry needs to improve the quality of its fish and lessen production cost to make its price competitive. Presently, the main obstacles of the industry are lack of good quality fish and high market price due to high production cost. Thus, it is crucial to address these issues to enable successful entry into the export market. Breeding programs to improve quality must be developed by government agencies in key production areas and assess avenues to lessen production cost. Improved fish quality will also benefit the local aquarists and increase the level of ornamental fish hobby engagements in the country. The development of the export market for freshwater ornamental fish will increase trade and provide an essential livelihood to ornamental fish producers in the country.

Moreover, all of the freshwater ornamental fish produced and traded in the country are all exotic and introduced species with no record of native or endemic species being traded. In countries like Sri Lanka, Thailand, and Malaysia, native species have been bred in captivity and traded as ornamental fish ( $\mathrm{Ng}$ and Tan 1997; Dey et al. 2014; Pal 2015). The Philippines needs to produce its own native ornamental fish species to become competitive in the market. This will also support the sustainability of the endemic species 
in its wild habitats.

Finally, the support of the government through an ornamental fish development program is essential and would play a vital role in the development of the sector, which has been successful in other priority aquaculture species in the country.

\subsection{Issues and Concerns}

From the tracer survey interviews and four focus group discussions conducted during the study, the issues and concerns of the marine and freshwater ornamental fish industry were identified and summarized in Table 9. The two sectors had different issues with each sector listing varied constraints between different stakeholders. For the marine ornamental sector, the general issues are the sustainability of the resource, seasonality of production due to extreme weather conditions and low buying price at the diver's level. Illegal methods of the collection also resulted in the banning of collection and transport of marine ornamentals in several areas. The main concerns of the marine ornamental fish sector revolve around restrictions on ornamental gathering and trade, but such policies were made by local government units to pre-empt further deterioration of resources and wild habitats. However, such regulations should take into account the living conditions of the diver households and must be geared towards regulations for sustainable harvest rather than banning. In many areas where extraction of marine ornamental fish is allowed, fish population is still significant, and such activity is deemed beneficial to the livelihood of the family of dependent diver-gatherers by the local government units. To ensure sustainability,

Table 9. Issues and concerns of the stakeholders of the ornamental fish industry in the Philippines.

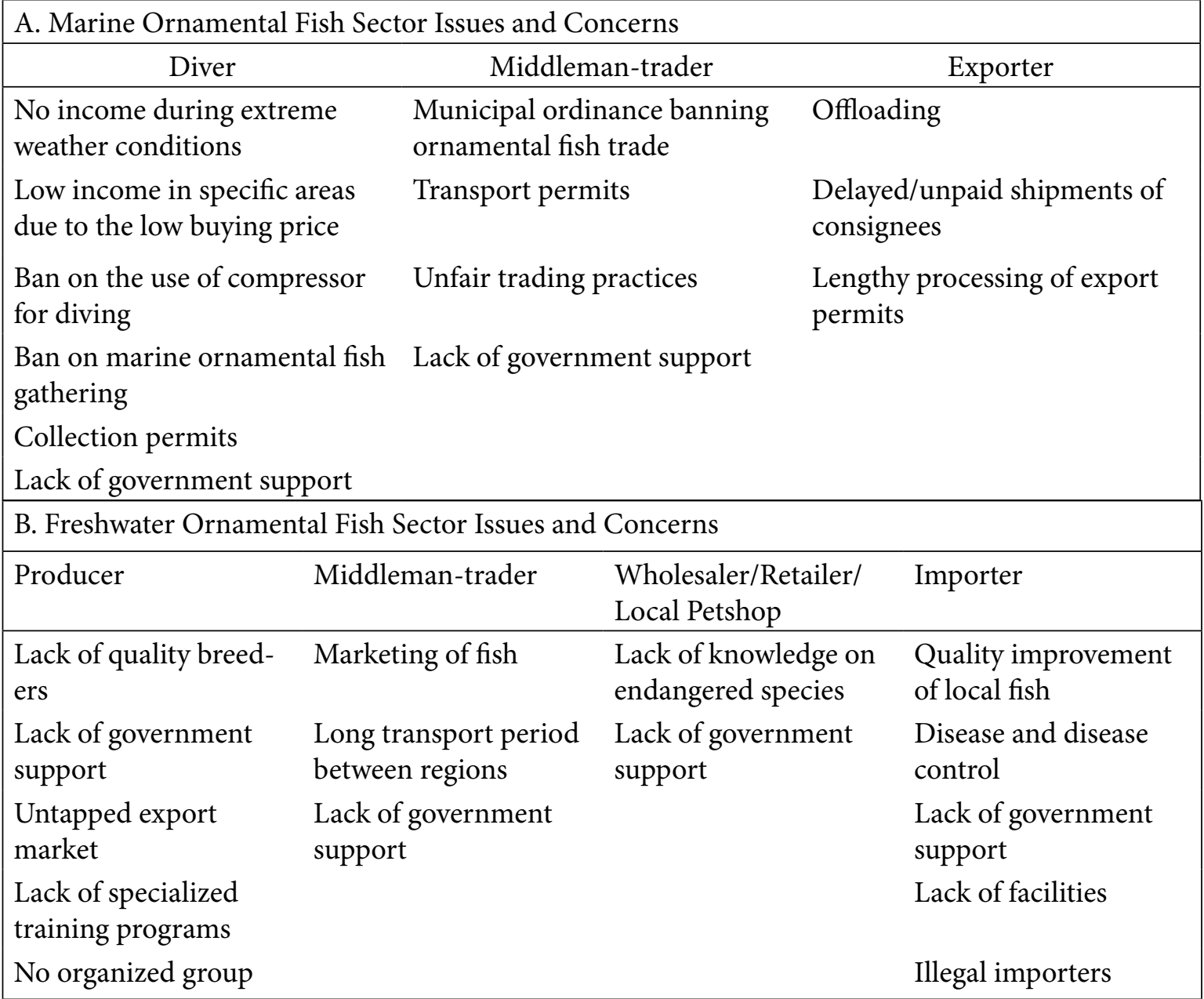


LGUs implemented resource sustainability programs such as declaration of marine sanctuary reserves. It is vital to strike a balance between livelihood benefits and sustainable fish population in these production areas.

Moreover, there should be a fair buying price at the diver's level to increase their income and decrease over-extraction of fish from the wild to meet the daily needs of their family. Marine ornamental fish aquaculture should also be developed and supported to provide a sustainable supply of captive-bred marine ornamental fish and minimize collection from the wild. In the freshwater ornamental fishery sector, general concerns in the industry were noted; from lack of good quality fish in the local market due to deteriorating quality of fish breeders to the lack of specialized training programs such as selective breeding and an untapped export market. An ornamental fish industry development program is needed to support the sector on this matter.

Ornamental fish is not a priority species of the government and may be the reason for lack of government support, which is a common issue for both marine and freshwater ornamental fish sectors. The key informant interviews done by the study showed that among the national centers and regional offices of BFAR, only NFRDI-NFFRDC and BFAR 4A-Calabarzon had supported the development program for ornamental fish funded by the office although several BFAR Regions had existing livelihood projects involving ornamental fish. The prioritization of species in the regions is mainly anchored on the national priority programs of BFAR. Thus, it is imperative that BFAR considers ornamental fish as one of the species to be supported for aquaculture development.

\section{CONCLUSION AND RECOMMENDATIONS}

The current state of ornamental fish in the country showed two scenarios: (1) a marine ornamental fish sector highly dependent on export of wild-caught species with production limited by the fair to poor state of coral reef areas and; (2) a freshwater ornamental fish sector with local production and import mainly traded for the local market with an untapped export market. The ornamental fish industry is a lucrative business that has broad prospects and opportunities for livelihood and trade if appropriate support development programs are initiated. The industry needs government support to attain its full potential through an ornamental fish industry devel- opment program for both the marine and freshwater ornamental fish sectors that will address key issues and concerns. For the marine ornamental fish sector, the technology for captive breeding of main export species is lacking and needs to be developed. Through captive-breeding, marine ornamental fish aquaculture will be able to provide sustainable supply of ornamental fish for trade and lessen the collection of fish from wild populations. It will also create a new sector in the industry which will generate additional employment and trade opportunities. Moreover, a fair buying price at the diver level should be ensured, so that diver gatherers benefit more from the marine ornamental fish trade and achieve the needed family income even with lesser number of fish collected from the wild. Furthermore, over-exploitation of marine ornamental fish may be addressed by providing an alternative or additional livelihood to diver households. For the freshwater ornamental fish sector, the high production of fish over the absorptive capacity of the local market is an indicator that the sector needs to venture into the export market where demand is still high. However, to be able to enter the export trade, there is a need to improve the quality of the locally produced fish and lower production cost to make its price competitive in the export market. Additionally, native freshwater species with potential as ornamental fish must be developed and produced through captive breeding to make the Philippines recognizable in the export market through its own fish species.

\section{A C K N O W L D G M EN T S}

The authors are grateful to the National Fisheries Research and Development Institute for funding the Ornamental Fish Project of FFRDC. The authors also thank all BFAR Regional Offices and Local Government Units that supported the conduct of survey interviews and FGDs in the regions as well to BFARFRQD and BFAR Fish Health Main Office. Special thanks to Ma. Lourdes Merilles for the proofreading and lay-outing of figures. The authors also extend their deepest gratitude to the two anonymous reviewers of this paper.

\section{REFER E N C E S}

Aliño PM, Nañola Jr CL, de Jesus DD, de Ramos RI, Balingit ACM, Robles LE, Arceo HO, Deocadez MR, Atrigenio M, Martinez RJS, et al. 2012. Status of Philippine coral reefs (2008-2011). In: Baria V, Muallil R, de Jesus DO, Samonte P, 
Ricafrente MV, Arceo H, Aliño PM eds. State of coasts: Sustaining the state of the coasts reporting. Quezon City: PhilReefs, Philippine Council for Agriculture, Aquatic and Natural Resources Research and Development and the Marine Science Institute, University of the Philippines. p.10-15.

[BFAR] Bureau of Fisheries and Aquatic Resources. 2015. Fisheries Sector: External Trade. Retrieved from BFAR Online Information System: http://bfar.da.gov.ph/profile?id=7\#post

[BFAR] Bureau of Fisheries and Aquatic Resources. 2014. Philippine Fisheries Profile 2014. PCA Bldg., Elliptical Road, Diliman, Quezon City. Available from: https://www.bfar.da.gov.ph/ files/img/photos/2014FisheriesProfile(Finalcopy).pdf.

BFAR One Stop Shop. 2015. Secondary information on marine ornamental fish export data. Pasay City: Bureau of Fisheries and Aquatic Resources.

Bruckner AW. 2005. The importance of the marine ornamental reef fish trade in the wider Caribbean Rev. Biol. Trop. (Int. J. Trop. Biol. ISSN-00347744) Vol. 53 (Suppl. 1): 127138.

[CNFIDP] Comprehensive National Fisheries Industry Development Program. 2016.

Comprehensive National Fisheries Industry Development Program 2016-2020. Quezon City. Bureau of fisheries and Aquatic Resources.

Dey VK. 2016. The Global Trade in Ornamental Fish. INFOFISH International [Internet]. [cited 2018 June 9]. p. 55-55. Available from http//:www.infofish.org.

Dey S, Ramanujam SN, Mahapatra BK. 2014. Breeding and development of ornamental hill stream fish Devario aequipinnatus (McClelland) in captivity. International Journal of Fisheries and Aquatic Studies; 1(4): 01-07.

Domínguez LM, Botella AS. 2014. An overview of marine ornamental fish breeding as a potential support to the aquarium trade and to the conservation of natural fish populations. Int. J. Sus. Dev. Plann. 9 (4): 608-632.
Kumar ATT, Gunasundari V, Prakash S. 2015. Breeding and Rearing of Marine Ornamentals. Advances in Marine and Brackishwater Aquaculture pp.101-107.

Herath HMTNB, Wijewardene LN. 2014. Ornamental fish trade in Sri Lanka: an economic perspective. International Journal of Environmental Sciences. 3 (8): 40-45.

Licuanan AM, Reyes MZ, Luzon KS, Chan MAA, Licuanan WY. 2017. Initial findings of the nationwide assessment of Philippines coral reefs. Philippine Journal of Science 146 (2): 177-185.

Ling H, Lim LY. 2005. The status of ornamental fish industry in Singapore. Singapore J Pri Ind 32: 59-69.

Livengood EJ, Chapman F.A., 2009. The ornamental fish trade: An introduction with Perspective for responsible aquarium cooperative extension service. Institute food and agricultural science, University of Florida Gainesville FL, 32611, p.230.

Moorhead JA, Zeng C. 2010. Development of Captive Breeding Techniques for Marine Ornamental Fish: A Review, Reviews in Fisheries Science, 18 (4):315-343.

Muyot FB, Mutia MTM, Manejar AJA, Guirhem GL, Munez MJ. 2019. Value chain analysis of marine ornamental fish industry in the Philippines. The Philippine Journal of Fisheries. 25 (2): 57-74.

Ng PKL, Tan HH. 1997. Freshwater fishes of Southeast Asia: potential for the aquarium fish trade and conservation issues. Aquarium Sciences and Conservation, 1: 79-90.

Orchavillo D, Hodgson G, Shuman C, Ruz R. 2004. Status of the Philippine marine aquarium fish trade. In p. 60-64. In DA-BFAR (Department of Agriculture-Bureau of Fisheries and Aquatic Resources). In turbulent seas: The status of Philippine marine fisheries. Coastal Resource Management Project, Cebu City, Philippines. $378 \mathrm{p}$.

Pal S. 2015. A study on Diversity of Indigenous Or- 
namental Fish Species available in Howrah District of West Bengal, India. International Journal of Applied and Pure Science and Agriculture (IJAPSA) 1 (8): 137-148.

[PSA] Philippine Statistics Authority. 2018. Census of Agriculture and Fisheries 2012. Philippine Statistics Authority. ISSN 0116-4007. Available from http://psa.gov.ph/sites/default/files/CAF2012Agri_Philippines.pdf.

[PSA] Philippine Statistics Authority. 2016. Philippine Fisheries Situationer 2009 to 2016. Philippine Statistics Authority. p. 47. Available from: https://psa.gov.ph/sites/default/files/FisheriesSituationer2016_0.pdf.
Rao VM, Kumar ATT. 2014. Captive Breeding and Hatchery Production of Mouth Brooding Jewel Cardinal Perch, Pterapogon Kauderni, (Koumanns, 1933) Using Brackish Water: The Role of Live Prey and Green Water Enrichment in Juvenile Production. J Aquac Res Development 5: 277 doi:10.4172/2155-9546.1000277.

Swet T, Pedersen M. 2018. A Coral Special Report: The State of Marine Breeder's Art, 2018. Coral Magazine March/April 2018 issue.

Teddlie C, Yu F. 2007. Mixed Methods Sampling: A Typology with Examples. Journal of Mixed Methods Research, 77-100.

Wood EM. 2001. Collection of coral reef fish for aquaria: Global trade, conservation issues and management strategies; Marine Conservation Society, Ross-on-Wye, UK. 